\title{
Pengembangan Dispenser Hand Sanitizer Automatis Terintegrasi Pendeteksi Suhu Tubuh untuk Pencegahan Penyebaran Covid-19
}

\author{
Mustarum Musaruddin*, Abdul Djohar, Bunyamin, Muh. Saparun \\ Program Studi Teknik Elektro, Fakultas Teknik, UniversitasHalu Oleo, Kendari, Indonesia
}

\begin{abstract}
Article history
Received: 30-12-2020

Revised: 20-03-2021

Accepted: 29-07-2021

*Corresponding Author: Mustarum Musaruddin Program Studi Teknik Elektro, Fakultas Teknik, UniversitasHalu Oleo, Kendari, Indonesia;
\end{abstract}

Email:mustarum@uho.ac.id
Abstract: The increase in the number of patients who have tested positive for Covid-19 continues to increase very significantly from time to time and there is no certainty when this outbreak will end. Therefore, anticipatory and preventive steps are needed to overcome these problems. One of the efforts to prevent the spread of the Covid-19 virus is to regularly wash hands and use hand sanitizers. However, not everyone is able to prepare hand sanitizers and not all public places are provided with hand washing facilities and hand sanitizers, even if there are, special personnel (operators) are needed to spray sanitizer and check body temperature with a thermo gun from a very close distance, which of course is this. It is also very vulnerable to the transmission of Covid-19. The purpose of this activity is to design and manufacture and provide appropriate technology for hand sanitizers and body temperature detectors to break the chain of the spread of Covid-19. The method used in this activity is to design, manufacture and test automatic hand sanitizer dispensers and disseminate technology at the urban village office in Kendari City. This community service activity has succeeded in producing an automatic hand sanitizer product that is integrated with a body temperature detection system and this tool has been implemented in one of the Kelurahan offices in Kendari City.

Keywords: covid-19; automatic hand sanitizer dispenser; body temperature detector

Abtrak: Pertambahan jumlah pasien yang dinyatakan positif Covid-19 terus meningkat dengan sangat signifikan dari waktu ke waktu dan belum ada kepastian kapan wabah ini akan berakhir. Oleh karena itu diperlukan langkah antisipatif dan preventif untuk mengatasi permasalahan tersebut. Salah satu upaya untuk pencegahan penularan virus Covid-19 ialah dengan rutin mencuci tangan dan menggunakan hand sanitizer. Namun, tidak semua orang mampu menyiapkan hand sanitizer dan tidak semua tempat umum disediakan tempat cuci tangan dan hand sanitizer, kalaupun ada maka dibutuhkan tenaga khusus (operator) untuk melakukan penyemprotan sanitizer dan pengecekan suhu tubuh dengan thermo gun dari jarak yang sangat dekat yang tentunya ini juga sangat rawan untuk penularan Covid-19. Tujuan dari kegiatan ini ialah mendesain dan membuat serta menyediakan teknologi tepat guna alat pembersih tangan dan pendeteksi suhu tubuh untuk memutus mata rantai penyebaran Covid-19. Metode yang digunakan pada kegiatan ini ialah mendesain, membuat dan menguji dispenser hand sanitizer automatis serta melakukan diseminasikan teknologi dikantor kelurahan di Kota Kendari. Kegiatan pengabdian masyarakat ini telah berhasil menghasilkan sebuahproduk Hand sanitizer automatis yang terintegrasi dengan system pendeteksi suhu tubuh dan alat ini telah diterapkan di salah satu kantor Kelurahan di Kota Kendari.

Kata Kunci: covid-19; dispenser hand sanitizer automatis; pendeteksi suhu tubuh 


\section{PENDAHULUAN}

Jumlah kasus infeksi virus covid-19 saat ini telah menembus angka 59.4 M dengan tingkat kematian mencapai 1.4 M jiwa, Indonesia sendiri telah mencapai angka 506,000 jiwa untuk kasus positif covid-19 dengan angka kematian 16,111 jiwa [1]. Sejak wabah Covid-19 ini, pemerintah telah menerbitkan kebijakan yang dianggap perlu untuk mencegah penyebaran wabah ini, langkah yang dilakukan diantaranya adalah social distancing, penyemprotan desinfektan di berbagai wilayah serta anjuran untuk senantiasa menggunakan masker, mencuci tangan dan menggunakan hand sanitizer.

Sasaran pemanfaatan teknologi dispenser automatis ini adalah lingkup perkantoran kota Kendari. Karena sejak diberlakukannya tatanan kebiasaan normal baru (New Normal) maka para pegawai telah kembali bekerja di kantor-kantor dengan menerapkan protocol kesehatan untuk Covid19 yaitu dengan menggunakan masker, jaga jarak, rutin mencuci tangan dan menggunakan hand sanitizer serta melakukan pengukuran suhu tubuh. Lokasi sasaran PKMI ini adalah kantor Kelurahan Lalolara, Kecamatan Kambu, Kota Kendari. Pemilihan lokasi sasaran karena jumlah masyarakat di Kelurahan Lalolara merupakan salah satu yang terbanyak dibanding kelurahan lainnya di kota Kendari serta lembaga ini merupakan salah satu kantor dengan mobilitas pengunjung dan layanan yang cukup tinggi di masa pandemic Covid-19.

Secara astronomis, Kecamatan Kambu terletak antara 3058'39" -4o4'45" Lintang Selatan, serta antara 122030'39" -122033'42" Bujur Timur. Kecamatan Kambu terdiri dari 4 kelurahan definitive yaitu Lalolara, Padaleu, Mokoau, dan Kambu. Secara administratif, ibukota kecamatan Kambu adalah kelurahan Lalolara. Dari sekitar 35,000 penduduk di kecamatan Kambu, jumlah penduduk terbesar berada di kelurahan Lalolara dengan jumlah penduduk berkisar 15,300 jiwa [2]. Dengan banyaknya masyarakat yang tinggal di Lalolara maka potensi penyebaran virus Covid 19 juga akan tinggi jika tidak segera dilakukan pencegahan sejak dini , terutama pada beberapa lokasi potensi penyebaran seperti kantor kelurahan yang melakuakan pelayanan kepada masyarakat terkait masalah kependudukan dan hal-hal administrative lainnya, selain itu beberapa fasilitas umum yang ada di kelurahan tersebut juga berpotensi sebagai pusat penyebaran Covid 19.

Masih rendahnya tingkat kesadaran masyarakat untuk menerapkan protokol kesehatan dalam masa pandemic Covid 19 merupakan sebuah permasalahan yang sering mengemuka belakangan ini. Sebagian orang belum memahami pentingnya langkah pencegahan terhadap Covid 19 seperti penggunaan masker, mencuci tangan dengan air dan menggunakan hand sanitizer. Selain masalah tersebut di atas, permasalahan lain yang tidak kalah pentingnya ialah Sebagian kantor layanan umum dan beberapa fasilitas umum belum dilengkapi dengan fasilitas pencuci tangan ataupun hand sanitizer. Hal lain terkait kondisi penggunaan alat hand sanitizer yang ada saat ini ialah bahwa alat tersebut masih harus bersentuhan langsung dengan pengguna dan adapula yang menempatkan petugas khusus untuk menyemprotkan ke tangan semua orang dari jarak dekat yang mana hal ini juga cukup beresiko terhadap penularan Covid 19.

Setelah mengamati permasalahan yang di hadapi mitra dalam upaya pencegahan penyebaran Covid 19, solusi yang diberikan ialah mendesain dan membuat perangkat untuk pembersih tangan automatis dengan yang dapat digunakan di kantor pelayanan masyarakat seperti kantor kelurahan serta fasilitas umum lainnya serta memberikan pelatihan penggunaan dan perawatan alat tsb.

Tujuan dari kegiatan ini ialah mendesain dan membuat serta menyediakan teknologi tepat guna sebagai dispenser pembersih tangan automatis yang terintegrasi dengan sistem pendeteksi suhu tubuh untuk memutus mata rantai penyebaran Covid-19. 


\section{METODE}

Tahapan pelaksanaan kegiatan pengabdian masyarakat ini adalah:

\section{a) Mendesain alat pembersih tangan automatis}

Pada tahap ini, semua komponen yang dibutuhkan diidentifikasi dan rangkaian yang diperlukan didesain dan dibuat dalam bentuk gambar rangkaian. Komponen dispenser ini terdiri dari komponen elektronik yang mendukung fungsi alat serta komponen untuk box panel, storage dan stand alat yang terbuat dari pipa PVC.

\section{b) Membuat alat pembersih tangan automatis}

Setelah semua komponen sudah tersedia dan gambar rangkaian sudah ada, maka untuk Langkah awal pembuatan rangkaian dilakukan di atas proto board untuk memastikan fungsi dari alat bekerja sesuai yang diinginkan. Lalu rangkaian yang sudah jadi dipindahkan kedalam papan PCB untuk lebih mempatenkan rangkaian tersebut agar komponen-komponen elektronik yang digunakan tidak mudah goyang.

c) Membuat Program untuk Mikrokontroller

Sebelum Mikrokontroller dapat bekerja sebagai otak dari alat yang dibuat, maka perlu dibuatkan sebuah Program atau coding berisi algoritma fungsi sesuai keinginan pengguna. Alat ini dibuat menggunakan Mikrokontroller jenis Arduino Nano dan software yang digunakan ialah ARDUINO versi 1.8.13.

d) Melakukan Uji Coba Alat

Sebelum alat ini diterapkan ke Masyarakat maka terlebih dahulu dilakukan pengujian di Laboratorium Teknik Elektro UHO.

e) Melakukan Diseminasi, Pelatihan Penggunaan dan Perawatan Alat dan Evaluasi

Setelah Dispenser hand sanitizer ini dinyatakan lolos hasil uji Laboratorium, maka Langkah selanjutnya ialah diseminasi alat ini ke Kantor yang telah ditentukan. Pada saat diseminasi, selain dilakukan sosialisasi pencegahan Covid-19 juga pelatihan penggunaan dan perawatan Dispenser hand sanitizer automatis ini. Untuk melihat impact dari kegiatan ini, setelah selesai kegiatan, diberikan kuesioner kepada pengguna teknologi dispenser hand sanitizer ini terkait manfaat dan impact penerapan hand sanitizer ini untuk memutus mata rantai penyebaran Covid-19 khususnya di tempat-tempat fasilitas umuma.

\section{HASIL DAN PEMBAHASAN}

Hasil yang diperoleh dari kegiatan pengabdian masyarakat ini terdiri atas perangkat keras (hardware), perangkat lunak (software), hasil pengujian alat, diseminasi yang dirangkaikan dengan pelatihan penggunaan dan perawatan alat serta evaluasi hasil kegiatan program kemitraan masyarakat ini.

\section{1) Perangkat Keras (Hardware)}

Dispenser hand sanitizer automatis terintegrasi pendeteksi suhu tubuh terdiri dari dua komponen utama yaitu teknologi tanpakontak (contactless) untuk menyemprotkan sanitizer ke tangan pengunjung serta teknologi pendeteksi suhu tubuh secara automatis yang ditampilkan pada panel display dan akan membunyikan alarm jika suhu tubuh pengunjung melebihi suhu normal yang telah ditentukan. Kedua system tersebut terintegrasi dan dikendalikan oleh sebuah Microcontroller. Selain itu ada pula sebuah storage penampungan sanitizer yang dapat dicustomize sesuai keinginan pengguna sehingga dapat menampung sanitizer dalam jumlah banyak.

Perangkat keras (hardware) dari dispenser hand sanitizer terintegrasi pendeteksi suhu tubuh dapat dilihat pada Gambar 1. Gambar 1a memperlihatkan tampak bagian dalam panel dispenser dan Gambar 1b menampilkan tampak bagian luar dari panel dispenser hand sanitizer automatis. Gambar 2 
memperlihatkan lebih detail tentang komponen utama dispenser hand sanitizer, dimana Gambar 2a ialah rangkaian untuk hand sanitizer automatis dan Gambar $2 b$ ialah rangkaian untuk pendeteksi suhu tubuh.

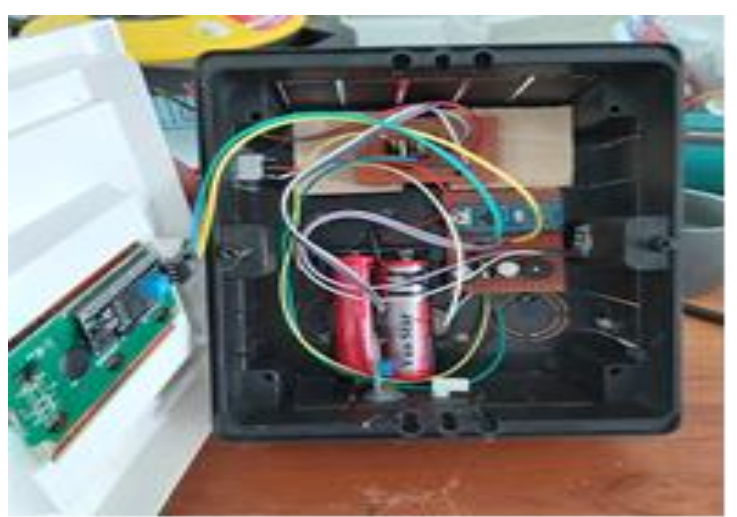

Gambar 1(a) Tampak bagian dalam panel dispenser

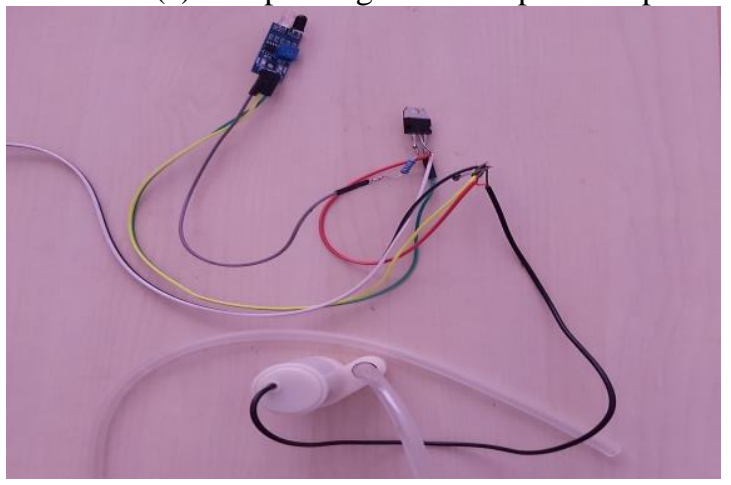

Gambar 2(a) Rangkaian sanitizer

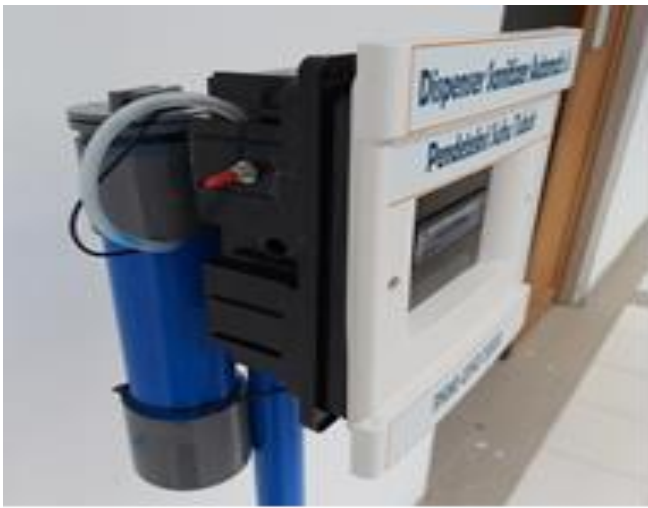

(b) Tampakbagianluarpanel dispenser

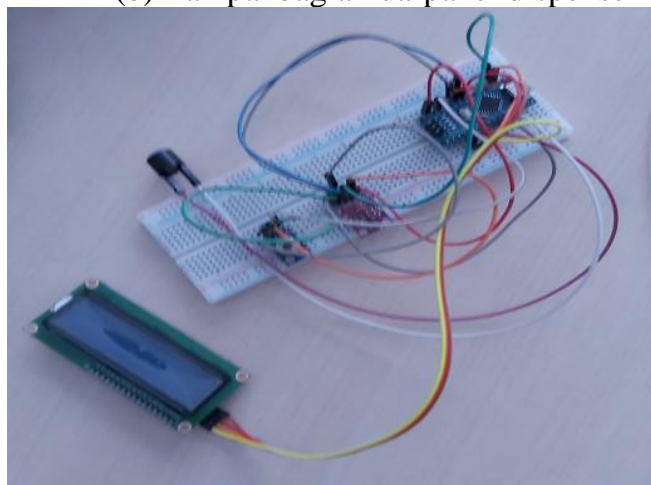

(b) Rangkaian pendeteksi suhu tubuh

\section{2) Perangkat Lunak (Software)}

Bahasa pemograman yang digunakan adalah bahasa pemograman $\mathrm{C}++$. Dalam project ini software yang digunakan untuk membuat program adalah software Arduino IDE 1.8.13

\section{3) Pengujian Alat}

Pengujian dilakukan untuk mengetahui apakah alat bekerja dengan normal, seperti menguji fungsi yang sesuai atau bekerja, menguji fitur alat, serta menguji respon alat. Tabel 1 memperlihatkan tabel pengujian alat.

Tabel 1 Pengujian Alat

\begin{tabular}{|c|c|c|c|}
\hline Pengujian & Fungsi & Output & $\begin{array}{c}\text { Hasil } \\
\text { Uji }\end{array}$ \\
\hline ndispenser & Menjalankansistem & Tampilanawal LCD & Berhasil \\
\hline Deteksisuhutubuh & Mengukursuhutubuh & Suhutubuhterukur & Berhasil \\
\hline Deteksisuhutinggi & $\begin{array}{l}\text { Mengukursuhudiatas } \\
38^{\circ} \mathrm{C}\end{array}$ & Bunyialarm & Berhasil \\
\hline $\begin{array}{l}\text { Deteksitangan pada } \\
\text { sensor proximity }\end{array}$ & Mendeteksitangan & $\begin{array}{l}\text { Penyemprotan hand } \\
\text { sanitizer }\end{array}$ & Berhasil \\
\hline
\end{tabular}

\section{4) Diseminasi Alat}

Diseminasi Dispenser hand sanitizer automatis dilaksanakan di Kelurahan Lalolara, Kecamatan Kambu, Kota Kendari. Kegiatan ini dirangkaikan dengan pelatihan penggunaan dan perawatan alat. Kegiatan ini diikuti oleh staf kelurahan dan disaksikan langsung oleh Lurah Lalolara. 
Gambar 3 memperlihatkan dokumentasi kegiatan diseminasi alat di lokasi mitra sasaran yang dirangkaikan dengan pelatihan penggunaan dan perawatan dispenser hand sanitizer automatis terintegrasi pendeteksi suhu tubuh. Dari hasil kuesioner yang diberikan kepada peserta dalam hal ini adalah staf kelurahan dan sebagian masyarakat peserta kegiatan di kelurahan Lalolara, diperoleh bahwa penerapan dispenser hand sanitizer automatis ini sangat bermanfaat untuk memutus matarantai penyebaran Covid-19 serta penggunaan dispenser hand sanitizer inisangat mudah sehingga direkomendasikan untuk dapat diterapkan di tempat-tempat fasilitas umum lainnya khususnya di kota Kendari.

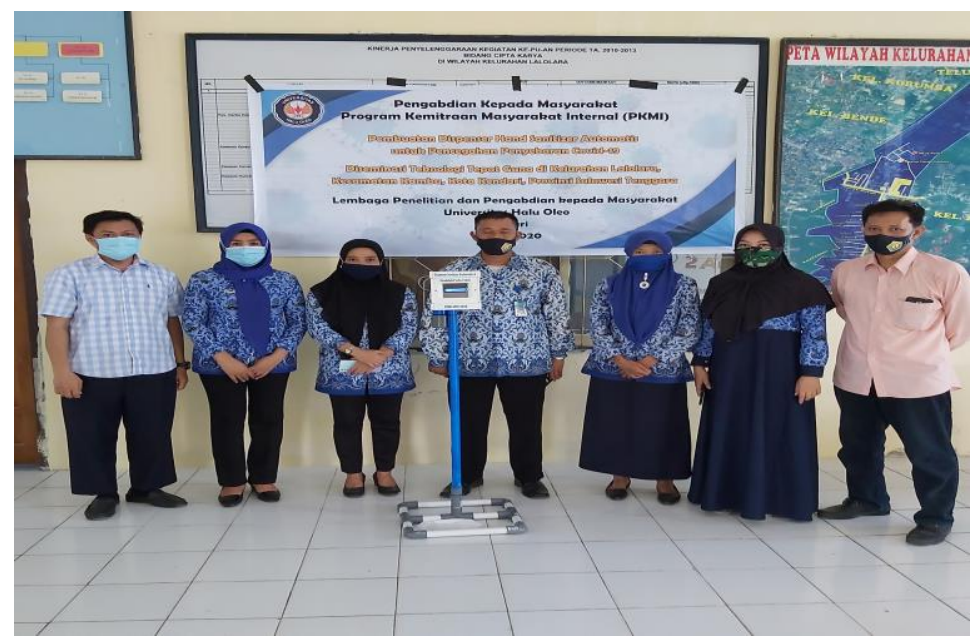

Gambar 3Diseminasi Dispense hand sanitizer di Kelurahan Lalolara, Kecamatan Kambu,Kendari

\section{Kesimpulan}

\section{KESIMPULAN DAN SARAN}

Kegiatan pengabdian masyarakat ini telah berhasil mendesain, membuat, melakukan pengujian serta mendesiminasikan Dispenser Hand Sanitizer Automatis terintegrasi Pendeteksi Suhu Tubuh di Kelurahan Lalolara, Kecamatan Kambu, Kota Kendari.Kelebihan dari Dispenser hand sanitizer ini, selain dilengkapi dengan dua fungsi utama untuk menyemprotkan hand sanitizer secara contactless dan pendeteksi suhu tubuh, storage sanitizer dapat dicustomize dan dispenser ini cukup portable dan bisa ditempatkan dimana saja.

\section{Saran}

Diharapkan bahwa teknologi ini dapat lebih dikembangkan lagi dan diterapkan di lingkungan kantor, sekolah, pusat perbelanjaan, bandara maupun di tempat-tempat fasilitas umum lainnya sebagai upaya pencegahan penyebaran Covid-19.

\section{Ucapan Terima Kasih}

Penulis mengucapkan terima kasih kepada Lembaga Penelitian dan Pengabdian Masyarakat Universitas Halu Oleo yang telah member dukungan financial terhadap kegiatan pengabdian ini.

\section{DAFTAR PUSTAKA}

Satgas Covid19 Indonesia. (2020). Data Covid 19 Indonesia, diaksestanggal 24 November 2020, dari: https://covid19.go.id/

Badan Pusat Statistik Kota Kendari. (2020). Kota Kendari dalam Angka, diaksestanggal 1 November 2020, dari: https://kendarikota.bps.go.id. 